\title{
SIMULTANEOUS DISTRIBUTION OF T-1824 AND I'181-LABELLED HUMAN SERUM ALBUMIN IN MAN ${ }^{1}$
}

\author{
By NORBERT FREINKEL,2 GEORGE E. SCHREINER,3 AND JOHN W. ATHENS * \\ (From the Departments of Biophysics and Surgical Physiology, Army Medical Service Graduate \\ School, Walter Reed Army Medical Center, Washington 12, D. C.)
}

(Submitted for publication September 18, 1952; accepted November 19, 1952)

The dilution of injected dyes (1-3), especially Evans Blue (T-1824) (4), has gained wide acceptance as a measure of plasma volume $(5,6)$. Recently, such an interpretation of the "T-1824 space" has been questioned. The challenges are based largely upon discordant volumes of distribution obtained after the simultaneous administration of T-1824 and labelled red blood cells (7-14), or $\mathrm{T}-1824$ and radioactive plasma proteins (15-18). Although others have been unable to confirm these differences (19-22), the reported divergences are in agreement, both in direction and magnitude. In every instance T-1824 was diluted to a greater extent than its companion indicator, and the ratios of T-1824 space/Indicator X space exceeded unity by 10 to 20 per cent.

The intravascular retention of $\mathrm{T}-1824$ depends upon the combination of free dye anions with serum albumin (23). Two hypotheses have been advanced to explain the discrepant results obtained with T-1824 and other indicators. First, there might be early abstraction of T-1824 by phagocytosis or staining of tissues $(15,24,25)$. Secondly, a disproportionate loss of T-1824 might occur during mixing by penetration into erythrocytepoor $(7-14,25,28)$ or even extravascular channels $(16,17,25-29)$. The first explanation rejects $\mathrm{T}-1824$ as an adequate protein label; the second explanation questions the immediate distribution of the T-1824-albumin complex.

Evidence points to the formation of a stable bond between T-1824 and albumin in vitro (30-33).

\footnotetext{
1 Presented in part at the fall meetings of the American Physiological Society, Salt Lake City, Utah, September 5-7, 1951 and New Orleans, Louisiana, September 3-5, 1952.

2 Present address: Thorndike Memorial Laboratory, Boston City Hospital, Boston, Mass.

${ }^{3}$ Present address : Dept. of Medicine, Georgetown University, College of Medicine.

4 Present address: Dept. of Medicine, University of Utah, Medical School.
}

The rapidity of this union, its stability and late metabolic fate have not been assessed in vivo. Much work has demonstrated the validity of $I^{181}$ as an albumin tag (34-38) and reference standard $(37,38)$. Experiments were therefore designed to evaluate the vagaries of dye behavior by comparing the simultaneous transit of $\mathrm{T}-1824$ and I $^{131}$-labelled human serum albumin in man. Attention was directed to the very early and the very late fate of $\mathrm{T}-1824$ in order to elucidate those factors operative during the middle or "plasma volume" phase of dye dilution.

Transport of T-1824 was examined during the time when the concentration of unbound dye is maximal ("first circulation phase") and during the later period when the rate of removal from the blood stream is probably independent of the mixing phenomena ("late metabolic phase").

The studies indicated that union of dye and protein in vivo is complete and virtually instantaneous and that the disappearance of $\mathrm{T}-1824$ thereafter approximates the actual exchange of albumin.

\section{MATERIALS AND METHODS}

Iodinated human serum albumin (I. H. S. A.) which incorporated two moles of iodine with one mole of albumin was obtained from a commercial source. 5 Initially, this preparation contained $200-400 \mu \mathrm{c}$ of $\mathrm{I}^{121}$ and 3 to $5 \mathrm{mgm}$. of albumin in $1 \mathrm{ml}$. Upon receipt in our laboratory, the radioactivity of each batch of I.H.S.A. was reassayed. In many instances, the nitrogen content was verified by micro-Kjeldahl digestion and the homogeneity of the albumin was confirmed by electrophoresis and ultracentrifugation. Residual unbound $\mathrm{I}^{\text {12 }}$ was measured by dialysis against distilled water for twenty-four hours and by precipitation with trichloracetic acid (TCA). Radioactivity recovered in the dialysis bath or in the TCA supernatant never exceeded 2 per cent of the total activity which was administered in any experiment.

Radioactivity was measured with a thin (1.4-1.8 mgm./ $\mathrm{cm}^{2}$ ) mica-end window Geiger-Mueller counter. Dupli-

5 Abbott Laboratories, North Chicago, Illinois. 
cate $0.5 \mathrm{ml}$. aliquots of plasma were pipetted onto filter paper discs cemented to the bottom of weighed planchets. One drop of alkaline 1 per cent gelatin supplemented with carrier iodide was added to each. Dried planchets were counted sufficiently long to reduce the standard deviation of the counts to less than 1 per cent. GeigerMueller tube characteristics and geometry were maintained constant. The self-absorption of each sample was corrected from a mass absorption curve.

Specimens for colorimetry were collected in siliconed test tubes containing $1 \mathrm{mgm}$. of dried heparin. Blood samples were centrifuged for fifteen minutes and hematocrits for forty-five minutes at 3,000 RPM. Plasma was subjected to two additional centrifugations and separations. All hemolyzed samples and those plasma specimens which still retained turbidity after three centrifugations were discarded. Optical density of T-1824 was determined at $620 \mathrm{~m} \mu$ in a Coleman Junior spectrophotometer using a control sample of plasma similarly diluted as a blank.

Specific gravities were determined on plasma specimens by the copper sulfate method (39). In serial observations these did not change sufficiently to warrant correction of observed plasma dye concentrations.

In studies of the first circulation, T-1824 and I.H.S.A. were mixed together, prior to administration, in proportions designed to leave at least 95 per cent of the dye in an unbound state. The concentrations were based on a theoretical maximal union of 11 to 12 moles of dye with 1 mole of albumin at $\mathrm{pH} 7.4(30,32)$. The presence of dye in a free state was substantiated by marked discoloration of cellophane strips immersed in this mixture (30). Pre-mixing of the two indicators was mandatory for comparison of their early simultaneous distribution. Work in this laboratory has shown that the addition of a marked excess of T-1824 to I.H.S.A. in vitro can increase the vulnerability of a portion of the iodinated protein ( 5 to 15 per cent) to loss of radioactivity in vivo (40). However, since this abnormal removal does not become manifest until several circulations through sites as yet undefined, the technique of pre-mixing does not invalidate comparisons during the first circulation. T-1824 and $\mathrm{I}^{12}$-labelled albumin were administered simultaneously by separate injections in studies of "the late metabolic phase."

In each experiment, a standard was prepared by diluting an identical amount of T-1824 and I.H.S.A. in distilled water to make a total volume of $1,000 \mathrm{ml}$. The distributions of T-1824 and I.H.S.A. were contrasted by graphing the concentration of dye and radioactivity in each plasma specimen as "percentage of the amount injected per ml. of plasma." The virtual volume occupied by each indicator at any given point can be derived by dividing this percentage into 100 .

Subjects were medical students, laboratory personnel and convalescent hospital patients between the ages of 18 and 35 . At the time of the determinations, subjects were recumbent and had fasted for at least twelve hours. Premedication consisted of 20 drops of Lugol's solution, given on the evening preceding the administration of I.H.S.A.

\section{EXPERIMENTS}

\section{The First Circulation}

Complete union of T-1824 and albumin requires less than 50 seconds at $37^{\circ} \mathrm{C}$. in vitro (31). Consequently, the potentiality for loss of unbound dye by diffusion, "staining" or reticulo-endothelial activity should be at a maximum during earliest mixing within the blood stream.

The first circulation was isolated from subsequent phases of mixing by the Stewart method (41) as modified by Kinsman, Moore, and Hamilton $(42,43)$. Comparative fates of T-1824 and I.H.S.A. during the first circulation were quantified by administering them concurrently and by separately estimating the flow of plasma from the mean dilution of each indicator. Values were obtained from the relationship

$$
f=\frac{60 I}{c t},
$$

where $f$ is flow of plasma in ml. per minute

$I$ is the amount injected (mgm. or counts)

$c$ is the mean concentration of the injected substance (mgm. per ml. or counts per ml.)

and $t$ is the time required for the first circulation (seconds).

TABLE I

Plasma flow rates during the first circulation

Simultaneous measurements with T-1824* and I'11 labelled human serum albumin

\begin{tabular}{lccccc}
\hline \hline & & \multicolumn{2}{c}{ Plasma flow rate $(m l . / m i n)}$. \\
$\begin{array}{l}\text { Patient } \\
\text { file no. }\end{array}$ & Weight & $\begin{array}{c}\text { Hemato- } \\
\text { crit }\end{array}$ & T-1824 & I.H.S.A. & $\frac{\text { T-1824 }}{\text { I.H.S.A. }}$ \\
\hline
\end{tabular}

kg.

A. Central Circulation ${ }^{* *}$

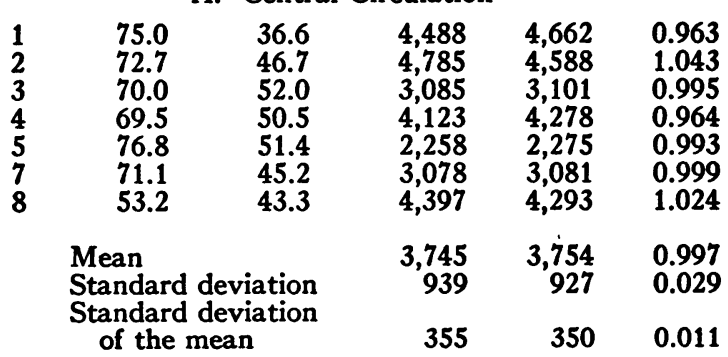

\begin{tabular}{lccccc}
\multicolumn{5}{c}{ B. Lower Extremity } \\
29 & 91.4 & 44.2 & 555 & 538 & 1.032 \\
30 a. & 87.3 & 34.6 & 512 & 507 & 1.010 \\
b. & & & 539 & 533 & 1.011
\end{tabular}

* T-1824 was mixed with I.H.S.A. prior to injection. The content of carrier albumin varied with specific activity but was never sufficient to bind more than $5 \%$ of the administered T-1824.

** Equivalent to plasma cardiac output. 
The logarithm of the absolute concentration in each plasma sample of T-1824 (O.D. T-1824 at $620 \mathrm{~m} \mu$ ) and of iodoalbumin (counts per second per $\mathrm{ml}$.) was plotted against time. Mean concentrations and $t$ were determined by extrapolation of the descending slope of these values to exclude recirculation. Extrapolated values which were not based on at least three successive points falling in a straight line were discarded.

T-1824 and I.H.S.A. were compared simultaneously during their first circulation through the heart and lungs and during their initial circuit through the lower extremity. It was felt that observations of early mixing in two such widely different vascular systems would adequately assess the immediate fate of $\mathrm{T}-1824$.

\section{A. Simultaneous transport through the heart and lungs}

Each subject was given a volume of 3-4 ml. containing 11 to $18 \mathrm{mgm}$. of Evans Blue and 1-3 $\mathrm{mgm}$. of albumin labelled with 50 to $60 \mu \mathrm{c}$ of $\mathrm{I}^{131}$. Delivery was made from a calibrated syringe through a polyethylene catheter introduced into the subclavian vein. Injection required less than one second. Blood samples were collected continuously from a short plastic adapter attached to a 14gauge retention needle within the femoral artery. The specimens were partitioned at measured two second in-

\section{SIMULTANEOUS TRANSIT OF TI824 AND II3I-LABELLED HUMAN ALBUMIN THROUGH THE LESSER CIRCULATION}

PT.\# 5 - INJECTION 17.8 MGMS. TI824 AND 0.89 MGM. SERUM ALBUMIN LABELLED WITH 67 MC IIBI INTO RIGHT SUBCLAVIAN VEIN

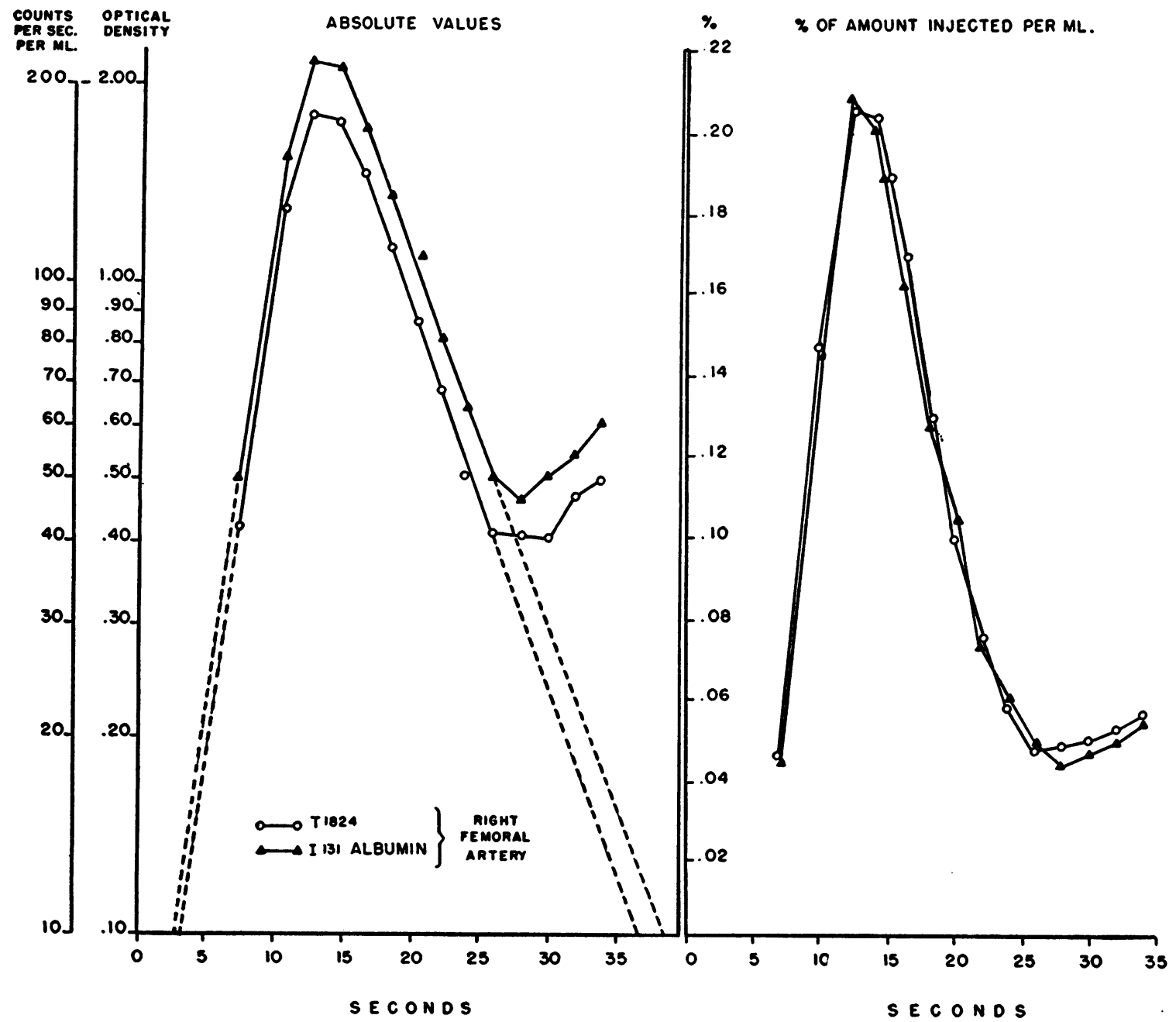

FIG. 1 


\section{SIMULTANEOUS TRANSIT OF TI824 AND II3I-LABELLED HUMAN ALBUMIN THROUGH LOWER EXTREMITY}

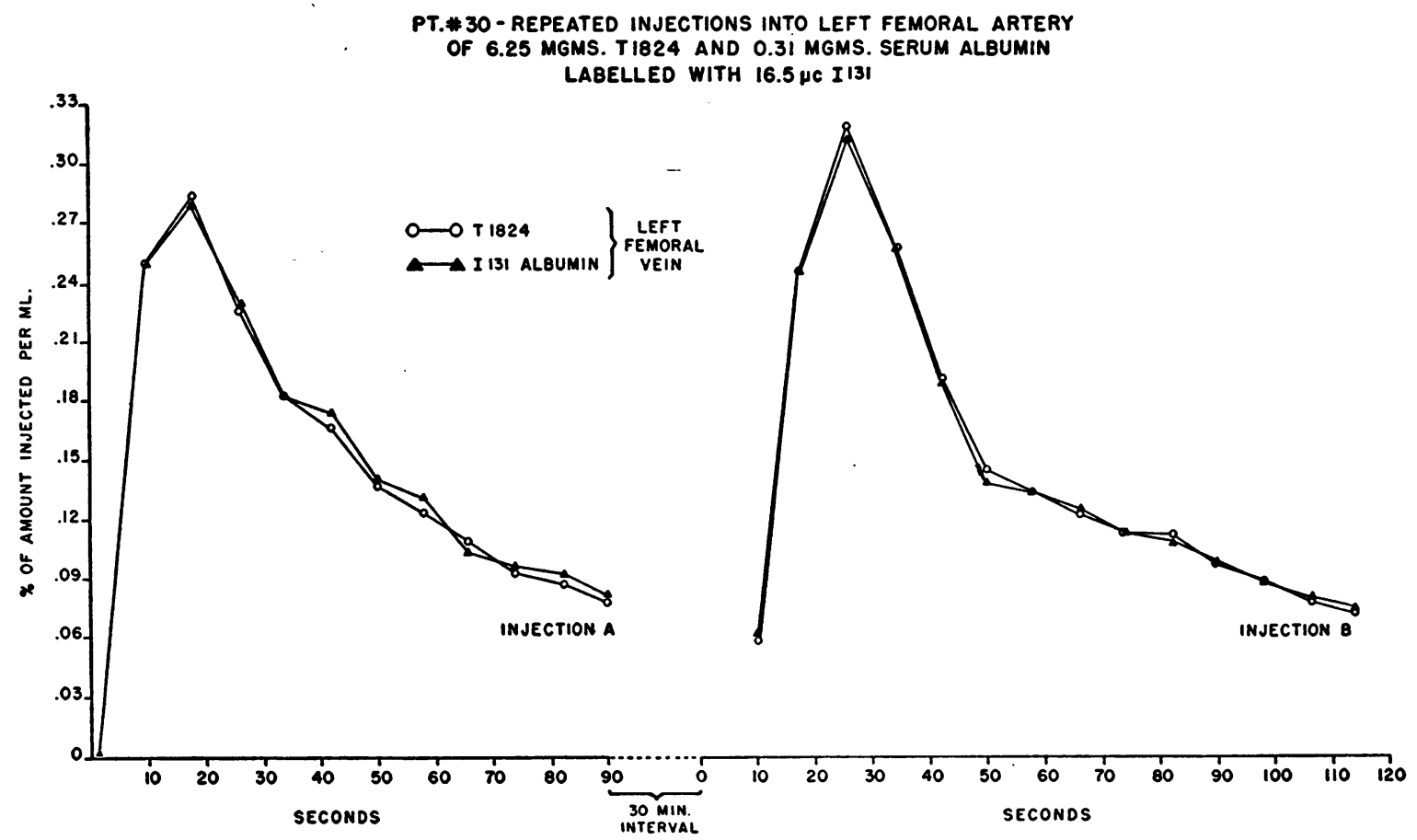

FIG. 2

tervals by manual direction of the adapter into test tubes. Sampling was continued well into the second recirculation.

Successful comparisons were done in seven subjects. T-1824/I.H.S.A. plasma flow ratios averaged 0.997 (Table I). Difference in minute output, stroke volume, or amount of T-1824 administered did not modify the ratio. Concentrations of the two indicators during the first circulation were superimposable when graphed as "percentage of the amount injected" (Figure 1).

Other investigators comparing the simultaneous movement of T-1824 and radioactive red blood cells also observed no preferential retention of dye within the lesser circulation $(44,45)$.

\section{B. Simultaneous transport through lower extremity}

A mixture of 6.25 to $10 \mathrm{mgm}$. T-1824 and 0.30 to 0.31 mgm. of albumin labelled with 16.5 to $20 \mu_{\mathrm{C}} \mathrm{I}^{181}$ in a total volume of 2.2 to $2.5 \mathrm{ml}$. was administered from a calibrated syringe. Delivery was made in less than one second through a 23-gauge needle inserted into the femoral artery in the femoral triangle. Venous plasma specimens were obtained at eight second intervals by syringe collection from an indwelling Cournand needle in the femoral vein. Three satisfactory comparisons were performed in two individuals (Table I). Rates of "plasma flow" were derived from the mean dilutions of T-1824 and I.H.S.A. These figures may not represent the true flow values for the lower extremity because of arterial streaming, inadequate mixing and variation in circulation time through deep and superficial vasculature.

T-1824/I.H.S.A. plasma flow ratios averaged 1.018 . Two determinations performed at thirty minute intervals in subject No. 30 indicate the reproducibility of the technique and the absence of a significant removal of unbound dye (24). Transport of both indicators was identical (Figure 2).

\section{The Late Metabolic Phase}

The rapidity of dye-protein union need not reflect the stability of the resulting complex. However, much in vitro evidence suggests that $\mathrm{T}-1824$ and albumin combine in a tight bond. At physiological $\mathrm{pH}$, there are a maximum of 11 sites in the albumin molecule for linkage with T-1824 $(30,32)$. Allen and Orahovats have estimated that "the binding energy from $\mathrm{T}-1824$ is 8,750 calories per mole" as opposed to "an energy change of about 3,000 calories in peptide bond formation between various amino acids" (32). The complex is not disrupted by simultaneous incubation with liver slices (33) and 0.96 mole of albumin per mole of dye suffice to prevent the staining of cellophane strips immersed in 0.002 per cent T-1824 (30).

At equilibrium within the plasma, less than 0.1 per cent of the dye exists as free dye anions (32). Persist- 
ence of dye within the pool of plasma proteins should be expected. Keith, Rowntree, and Geraghty in 1915 described gross retention of Brilliant Vital Red within the bloodstream for several days (1). Prolonged discoloration of plasma after the administration of $\mathrm{T}-1824$ was also observed by Dawson, Evans, and Whipple (3). However, we have been unable to discover any reports of quantitative measurements of T-1824 plasma levels in humans which were extended beyond one day.

Removal of dye from the circulation will be determined by metabolic processes alone only after T-1824 has equilibrated throughout its ultimate compartment of distribution. Therefore studies were instituted to evaluate the late disappearance of the T-1824-albumin complex.

\section{A. Twenty-four hour plasma levels of T-1824}

Twenty-seven subjects were given 15 to $25 \mathrm{mgm}$. of T-1824. Specimens of blood were collected at intervals of five minutes during the first thirty minutes and another specimen was taken twenty-four hours following the administration of dye. A "zero-time" plasma level of T-1824 was derived by the semilogarithmic extrapolation of the early dye disappearance. Twenty-four hour plasma levels were expressed as a percentage of this initial con- centration and as a percentage of the amount injected (Table II).

The residual T-1824 in the plasma averaged 50. 7 per cent after twenty-four hours, and was independent of the amount of dye given and the level of circulating plasma proteins. LeVeen and Fishman made identical observations in eighteen human subjects, and reported an average removal of $46.5 \%$ of $\mathrm{T}-1824$ from the circulation in one day (46).

These twenty-four hour values are in good agreement with figures reported by other workers using $\mathrm{I}^{121}$ labelled human serum albumin in man $(17,38,47)$, and $\mathrm{S}^{28}(48), \mathrm{C}^{16}(49,50)$ and $\mathrm{N}^{18}$ (51) labelled preparations of plasma proteins in dogs.

B. The late simultaneous distribution of T-1824 and $I^{101}$. labelled human serum albumin

Ten subjects were given 25 to $50 \mathrm{mgm}$. of dye and 0.40 to $3.0 \mathrm{mgm}$. of I.H.S.A. labelled with 40 to $60 \mu \mathrm{c}$. of $\mathrm{I}^{131}$. Both indicators were dissolved in equal volumes (10 ml.) and administered simultaneously into separate arm veins after the collection of a control plasma blank.

Fasting, morning blood specimens were secured at one or two day intervals for seven or eight days. Spectro-

TABLE II

Twenty-four hour plasma level of T-1824

\begin{tabular}{|c|c|c|c|c|}
\hline $\begin{array}{l}\text { Patient } \\
\text { file no. }\end{array}$ & Weight & $\begin{array}{l}\text { Serum } \\
\text { albumin }\end{array}$ & $\frac{24 \text { hour concentration }}{\times 100}$ & $\frac{24 \text { hour concentration } / \mathrm{ml}}{\times 100}$ \\
\hline $\begin{array}{r}3 \\
4 \\
5 \\
5 \\
10 \\
32 \\
33 \\
37 \\
38 \\
39 \\
40 \\
41 \\
43 \\
44 \\
47 \\
48 \\
49 \\
50 \\
51 \\
52 \\
53 \\
54 \\
55 \\
56 \\
57 \\
58 \\
64 \\
65\end{array}$ & $\begin{array}{c}\text { kg. } \\
70.0 \\
69.5 \\
76.8 \\
70.5 \\
90.6 \\
69.3 \\
75.0 \\
79.5 \\
81.8 \\
65.5 \\
75.0 \\
62.7 \\
62.7 \\
85.5 \\
75.0 \\
63.6 \\
70.7 \\
74.5 \\
81.4 \\
67.3 \\
49.1 \\
68.6 \\
68.9 \\
96.8 \\
75.9 \\
78.2 \\
63.6\end{array}$ & $\begin{array}{c}\text { gm. \% } \\
2.88 \\
3.72 \\
3.85 \\
3.77 \\
- \\
4.20 \\
3.87 \\
3.76 \\
- \\
3.34 \\
3.12 \\
4.01 \\
4.42 \\
4.36 \\
4.00 \\
4.13 \\
4.24 \\
4.24 \\
3.99 \\
3.96 \\
3.90 \\
3.79 \\
4.19 \\
4.00 \\
3.83\end{array}$ & $\begin{array}{l}46.8 \\
53.3 \\
43.4 \\
55.5 \\
37.5 \\
45.9 \\
40.1 \\
46.4 \\
42.5 \\
47.3 \\
50.4 \\
51.7 \\
61.2 \\
54.2 \\
55.0 \\
59.5 \\
60.8 \\
48.3 \\
50.0 \\
57.8 \\
54.9 \\
55.5 \\
51.8 \\
49.5 \\
50.4 \\
+4.2 \\
56.0\end{array}$ & $\begin{array}{l}.0169 \\
.0208 \\
.0193 \\
.0172 \\
.0111 \\
.0141 \\
.0149 \\
.0144 \\
.0153 \\
.0172 \\
.0145 \\
.0171 \\
.0219 \\
.0167 \\
.0187 \\
.0254 \\
.0238 \\
.0190 \\
.0145 \\
.0177 \\
.0248 \\
.0169 \\
.0219 \\
.0107 \\
.0165 \\
.0144 \\
.0208\end{array}$ \\
\hline \multicolumn{3}{|c|}{$\begin{array}{l}\text { Mean } \\
\text { Standard deviation } \\
\text { Standard deviation of the mean }\end{array}$} & $\begin{array}{r}50.7 \\
6.2 \\
1.2\end{array}$ & $\begin{array}{l}.0176 \\
.0038 \\
.0007\end{array}$ \\
\hline
\end{tabular}

* The semilogarithmic plot of dye disappearance during the first thirty minutes was extrapolated to "zero time" to derive the initial concentration of T-1824. 
THE LATE TRANSPORT OF T1824 AND II3I-LABELLED HUMAN SERUM ALBUMIN
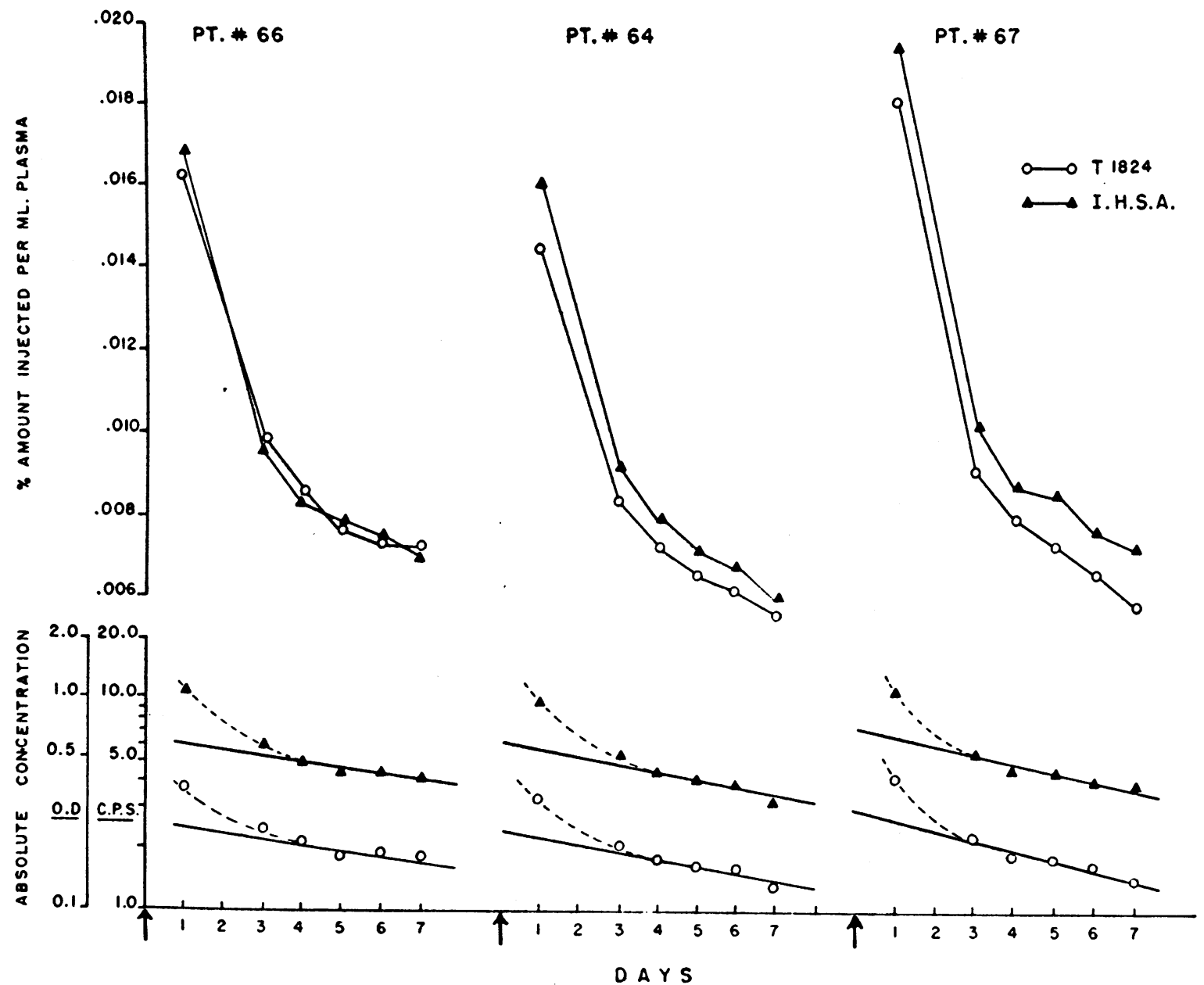

Frg. 3

photometric estimations of dye concentration were performed immediately. The initial undyed specimens of plasma were employed as colorimetric reference standards and kept frozen between analyses. The plasma content of dye in subjects who had received only $25 \mathrm{mgm}$. of T-1824 approximated 80 per cent transmittance at the end of one week. No readings exceeded this arbitrary limit of sensitivity.

The rates of disappearance of T-1824 and I.H.S.A. were compared in three ways. 1) Daily plasma concentrations of each indicator were graphed as "percentage of the amount administered" (Figure 3). Disappearance of dye and radioactivity was approximately exponential after two to three days. 2) "Apparent biological halflives" were derived for T-1824 and I.H.S.A. by standard graphic analysis of their late disappearance slopes (Table III). Such analysis need not reflect true rates of turnover since observations were not extended beyond one week and since T-1824 and I.H.S.A. were not ad- ministered by infusion techniques. The measurements were intended only for semi-quantitative comparison of the two indicators. 3) The late slopes were extrapolated to zero-time, and "total distribution compartments" were estimated for T-1824 and I.H.S.A. by dividing the amount injected by the theoretical concentration of each indicator at zero time (Table III). ${ }^{6}$

Three types of relationships were observed in the ten studies. In four subjects, the daily decrements of T-1824 and I.H.S.A. were superimposable (Figure 3, Pt. No. 66). In five subjects each successive sample of plasma contained progressively less T-1824 than I.H.S.A. (Figure 3,

6 These represent minimum virtual volumes since differences in the concentrations of intravascular and extravascular protein were disregarded in the calculation. Substitution of specific activities ( $\mathrm{mgm}$. dye/gm. albumin or counts I.H.S.A./gm. albumin) in the denominator would not have changed the comparative relationships. 
TABLE III

Comparison of the late distribution and "biological half-life" of T-1824 and I131 labelled human serum albumin

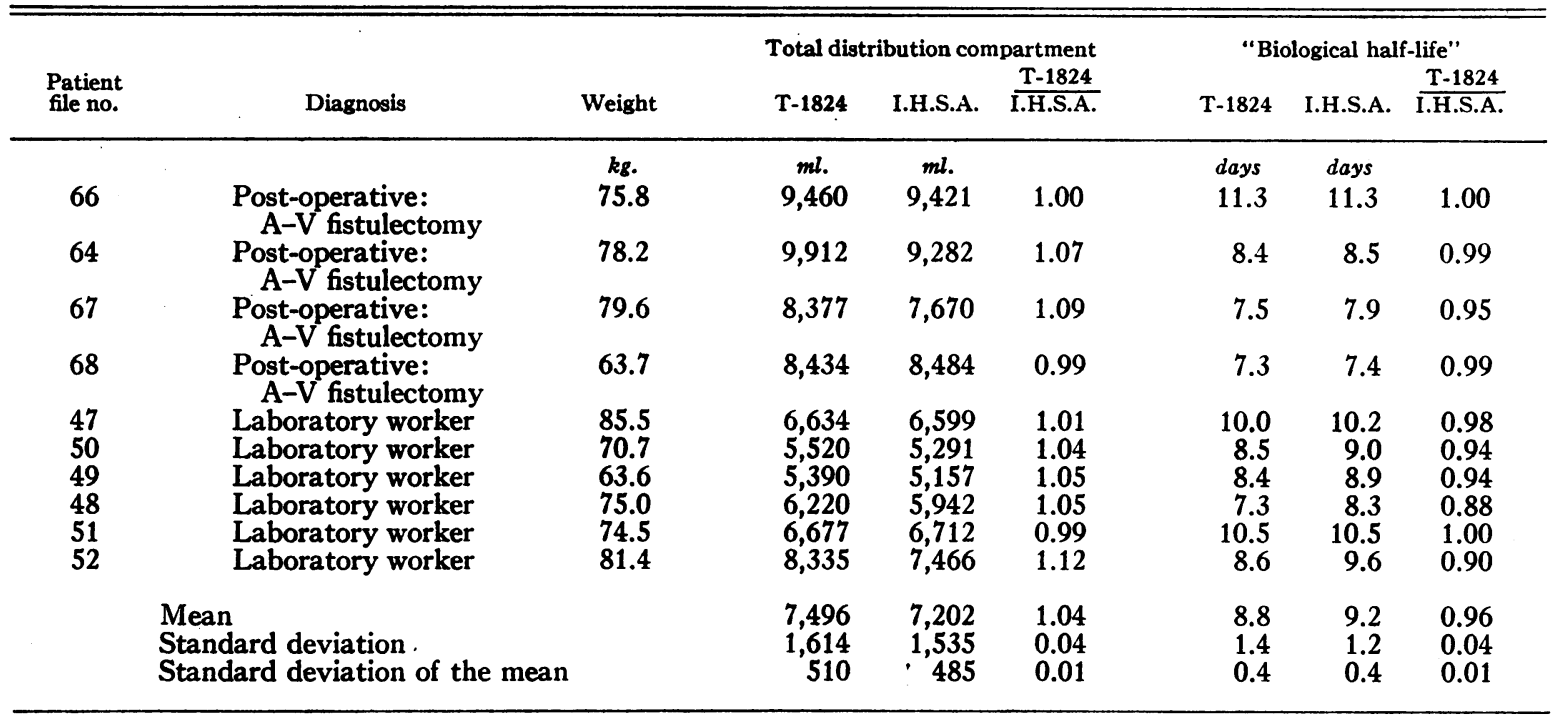

Pt. No. 67). Only one individual demonstrated a pattern compatible with an early discontinuous abstraction of. dye. In this subject, there was a divergence of the two indicators on the first day and a relatively constant difference throughout the succeeding week (Figure $3, \mathrm{Pt}$. No. 64). T-1824/I.H.S.A. "biological half-life" ratios averaged 0.96 ; T-1824/I.H.S.A. "total distribution compartment" ratios averaged 1.04. Values obtained with the two indicators were never more divergent than 12 per cent. All disparities were in the direction of more rapid loss and greater dilution of T-1824 and hence would suggest that these are not the result of methodological error. More studies will be necessary to define the true limits of potential divergence.

\section{DISCUSSION}

Little transcapillary exchange occurs normally within the lesser circulation (52). However, this system presents ample surface for "staining" of reticulo-endothelium or capillary endothelium since the pulmonary circulation includes "the richest capillary network in the body" (53), and lymphoid tissue within the lung exceeds that of liver or spleen (54). The peripheral circuits have less potential for phagocytosis although there is much exchange in these areas by diffusion and filtration. An identical dilution has been demonstrated for T-1824 and $\mathrm{I}^{181}$-labelled albumin during their first circulation through the heart and lungs as well as the lower extremity. This indicates that the union of T-1824 and plasma protein in vivo is complete and prompt.
In rare instances, such as in secondary amyloidosis $(55,56)$ or following the administration of polyvinyl pyrrolidone (57), there may be successful competition for $\mathrm{T}-1824$ by abnormally reactive substances whose dye affinities exceed those of plasma proteins.

The present studies attest to the prolonged stability of the dye-albumin complex in normal man. Over a period of one week, both T-1824 and I.H.S.A. disappeared at identical rates in four of ten simultaneous comparisons. The divergent turnovers which were observed in the remaining subjects may represent true metabolic differences.

$\mathrm{T}-1824$ and $\mathrm{I}^{131}$ affix at different sites in the albumin molecule. The dye "tags" albumin by linkage with the epsilon ammonium of lysine (58) whereas the tyrosyl groups are labelled in the process of iodination (59). Several factors may, therefore, complicate any evaluation of the relative fates of different albumin labels. It is not known whether the albumin molecule is metabolized as a unit or by replacement of constituent peptide groups. The extent of amino acid reutilization subsequent to the breakdown of albumin within the cell is also unknown. T-1824 may be permanently removed after cellular penetration by combination of dye with the dibasic amino acids of nucleoproteins (32). In contrast, any intracellular incorporation of iodinated tyrosyl residues into newly synthesized plasma 
proteins would modify the relative decrement of plasma radioactivity and prolong the apparent "half-life" of I.H.S.A. These are fundamental questions in protein chemistry and beyond the scope of this investigation. Nevertheless, the data do demonstrate that the late disappearance of T-1824 is not markedly incompatible with the actual turnover of albumin.

The concept of "total distribution compartments" has been introduced to compare the ultimate and minimum virtual volumes which $\mathrm{T}-1824$ and I.H.S.A. would have occupied if their equilibration with all the exchangeable albumin had been instantaneous. Others have used similar extrapolation techniques to quantify the absolute "exchangeable pools" of slowly mixing metabolites $(38,60-62)$. It may be pertinent to examine the potential error which such extrapolation can introduce.

Prior to the completion of mixing, there are varying amounts of label with each aliquot of albumin in the diverse subdivisions of the true albumin "space." Thus, although a constant amount of albumin is metabolized per unit of time, there is an inconstant sampling of the labelled albumin. If albumin is catabolized in the rapidly equilibrating portion of the albumin pool, protein of high specific activity may be disproportionately lost throughout mixing. Plasma concentrations of T-1824 or I.H.S.A. may thereby be artifactually depressed at the end of mixing (i.e., after two to three days) and any "space" derived by extrapolation would be too large. Similarly, if albumin metabolism occurs in areas which equilibrate slowly, protein of disproportionately low specific activity will be sampled during mixing and extrapolation to "zero time" would yield a space which is too small. The appearance of measurable amounts of dye (63) and radioactivity (64) in the bile soon after the administration of T-1824 and I.H.S.A. suggests that much of the normal breakdown of albumin occurs in areas where exchange is rapid, as in the liver.

No attempt has been made here to define that fraction of the total T-1824 "space" (commonly called "plasma volume") which is measured by the ten-minute to half-hour dilution of dye. It does not seem unreasonable that disproportionate extravascular dilution of dyed protein might occur during early mixing within the blood stream even as disproportionate metabolism of dyed protein is possible during prolonged distribution within the "total T-1824 space." Extrapolation would not account correctly for either type of disproportionate removal. The losses thereby introduced could explain the incomplete recovery of dye by viviperfusion techniques $(25,28)$ and the conflicting reports of early dye dilution $(7-14,19,20)$. Obviously alternative explanations exist. However, the present evidence does not support any criticism of T-1824 methods which is based purely on delayed and unstable union of dye and protein.

\section{SUMMARY}

1. The distribution of $\mathrm{T}-1824$ in normal man has been examined during the initial and the late phases of dye dilution and metabolism.

2. Dilution of $\mathrm{T}-1824$ did not exceed that of concurrently administered $\mathrm{I}^{131}$-labelled human serum albumin in seven measurements of the first circulation through the heart and lung and in three studies of the first circulation through the lower extremity. No support could be found for the concept of immediate abstraction of dye by tissues.

3. In twenty-seven studies, the twenty-four hour plasma levels of T-1824 averaged 50.7 per cent of the initial dye concentration.

4. Following separate, simultaneous administrations of T-1824 and I.H.S.A. to ten subjects, removal and dilution of dye did not exceed the concomitant decline of plasma radioactivity by more than 12 per cent during one week of serial observations.

5. Disproportionate sampling has been suggested as a source of error in extrapolation techniques. Such disproportionate sampling can be anticipated if a labelled substance is mixed progressively throughout a series of compartments which differ in their intrinsic constants of equilibration and disposition.

\section{ACKNOWLEDGMENTS}

We are grateful for the continued encouragement of Colonel Roy D. Maxwell and Dr. Robert W. Clarke. We are indebted to the resident and nursing staff of Walter Reed Army Hospital for their assistance in the studies of patients and to Dr. Edward D. Freis of Georgetown University Medical School for permission to study Subject 1 and Subject 2. It is a pleasure to acknowledge 
the help of Dr. Caspar W. Hiatt and Mr. Sydney Breese in the electrophoretic and ultracentrifugal analyses and the technical assistance of Sgt. James J. Dooley. The valuable suggestions of Dr. Franklin $H$. Epstein in the preparation of this manuscript are greatly appreciated.

\section{REFERENCES}

1. Keith, N. M., Rowntree, L. G., and Geraghty, J. T., A method for the determination of plasma and blood volume. Arch. Int. Med., 1915, 16, 547.

2. Hooper, C. W., Smith, H. P., Belt, A. E., and Whipple, G. H., Blood volume studies. I. Experimental control of a dye blood volume method. Am. J. Physiol., 1920, 51, 205.

3. Dawson, A. B., Evans, H. M., and Whipple, G. H., Blood volume studies. III. Behavior of a large series of dyes introduced into the circulating blood. Am. J. Physiol., 1920, 51, 232.

4. Gibson, J. G., 2nd, and Evans, W. A., Jr., Clinical studies of the blood volume. I. Clinical application of a method employing the azo dye "Evans Blue" and the spectrophotometer. J. Clin. Invest., 1937, $16,301$.

5. Reeve, E. B., Methods of estimating plasma and total red cell volume. Nutr. Abstr. and Rev., 1948, 17, 811.

6. Gregersen, M. I., Blood volume. Annual Review of Physiology XIII, 1951, 397-412.

7. Hahn, P. F., Ross, J. F., Bale, W. F., Balfour, W. M., and Whipple, G. H., Red cell and plasma volumes (circulating and total) as determined by radio iron and by dye. J. Exper. Med., 1942, 75, 221.

8. Gibson, J. G., 2nd, Peacock, W. C., Seligman, A. M., and Sack, T., Circulating red cell volume measured simultaneously by the radioactive iron and dye methods. J. Clin. Invest., 1946, 25, 838.

9. Barnes, D. W. H., Loutit, J. F., and Reeve, E. B., A comparison of estimates of circulating red blood cell volume given by the Ashby marked red cell method and the T-1824-hematocrit method in man. Clin. Sc., 1948, 7, 135.

10. Hevesy, G., Köster, K. H. S $\phi$ rensen, G., Warburg, E., and Zerahn, K., The red corpuscle content of the circulating blood as determined by labelling the erythrocytes with radio-phosphorus. Acta med. Scandinav., 1944, 116, 561.

11. Reeve, E. B., and Veall, N., A simplified method for the determination of circulating red-cell volume with radioactive phosphorus. J. Physiol., 1949, 108, 12.

12. Wasserman, L. R., Yoh, T., and Rashkoff, I. A., Blood volume determination: comparison of $\mathrm{T}-1824$ and $P^{20}$ labelled red cell methods. J. Lab. \& Clin. Med., 1951, 37, 342.

13. Nachman, H. M., James, G. W., III, Moore, J. W., and Evans, E. I., A comparative study of red cell volumes in human subjects with radioactive phosphorus tagged red cells and T-1824 dye. J. Clin. Invest., 1950, 29, 258.
14. Meneely, G. R., Wells, E. B., and Hahn, P. F., Application of the radioactive red cell method for determination of blood volume in humans. Am. J. Physiol., 1947, 148, 531.

15. Wish, L., Furth, J., and Storey, R. H., Direct determinations of plasma, cell and organ-blood volumes in normal and hypervolemic mice. Proc. Soc. Exper. Biol. \& Med., 1950, 74, 644.

16. Krieger, H., Storaasli, J. P., Friedell, H. L., and Holden, W. D., A comparative study of blood volume in dogs. Proc. Soc. Exper. Biol. \& Med., 1948, 68, 511.

17. Storaasli, J. P., Krieger, H., Friedell, H. L., and Holden, W. D., The use of radioactive iodinated plasma protein in the study of blood volume. Surg., Gynec., \& Obst., 1950, 91, 458.

18. Aust, J. B., Chou, S. N., Marvin, J. F., Brackney, E. L., and Moore, G. E., A rapid method for the clinical total blood volume determination using radioactive iodinated human serum albumin (RIHSA). Proc. Soc. Exper. Biol. \& Med., 1951, 77, 514.

19. Root, W. S., Roughton, F. J. W., and Gregersen, M. I., Simultaneous determinations of blood volume by $\mathrm{CO}$ and dye $(\mathrm{T}-1824)$ under various conditions. Am. J. Physiol., 1946, 146, 739.

20. Mayerson, H. S., Lyons, C., Parson, W., Nieset, R. T., and Trautman, W. V., Jr., Comparison of results of measurement of red blood cell volume by direct and indirect technics. Am. J. Physiol., 1948, 155, 232.

21. Crispell, K. R., Porter, B., and Nieset, R. T., Studies of plasma volume using human serum albumin tagged with radioactive iodine ${ }^{121}$. J. Clin. Invest., 1950, 29, 513.

22. Gregersen, M. I., Boyden, A. A., and Allison, J. B., Direct comparison in dogs of plasma volume measured with T-1824 and with antigens. Am. J. Physiol., 1950, 163, 517.

23. Gregersen, M. I., and Rawson, R. A., The disappearance of T-1824 and structurally related dyes from the blood stream. Am. J. Physiol., 1943, 138, 698.

24. Cruickshank, E. W. H., and Whitfield, I. C., The behavior of T-1824 (Evans's Blue) in circulating blood and a modified method for the estimation of plasma volume. J. Physiol., 1945, 104, 52.

25. McLain, P. L., Ruhe, C. H. W., and Kruse, T. K., Concurrent estimates of blood volume in animals by bleeding and dye methods. Am. J. Physiol., $1951,164,611$.

26. Lawson, H. C., Overbey, D. T., Moore, J. C., and Shadle, O. W., Mixing of cells, plasma, and dye $\mathrm{T}-1824$ in the cardiovascular system of barbitalized dogs. Am. J. Physiol., 1947, 151, 282.

27. Lawson, H. C., Overbey, D. T., Shadle, O. W., and Moore, J. C., Effect of plasma injection on dye and cell content of arterial blood. Am. J. Physiol., 1947, 151, 303. 
28. Lawson, H. C., Rappaport, D. B., and Ramirez, A., The recovery of injected dye and the yield of blood cells by perfusion of the cardiovascular system in barbitalized dogs. Am. J. Physiol., 1946, 147, 412.

29. Peters, J. P., The role of sodium in the production of edema. New England J. Med., 1948, 239, 353.

30. Rawson, R. A., The binding of T-1824 and structurally related diazo dyes by the plasma proteins. Am. J. Physiol., 1943, 138, 708.

31. Barnes, D. W. H., Loutit, J. F., and Reeve, E. B., Observations on the estimate of the circulating red blood cell volume in man given by $\mathrm{T}-1824$ and the hematocrit, with special reference to uncorrected dye loss from the circulation. Clin. Sc., 1948, 7, 155.

32. Allen, T. H., and Orahovats, P. D., Combination of Toluidine dye isomers with plasma albumin. Am. J. Physiol., 1950, 161, 473.

33. Allen, T. H., and Orahovats, P. D., Kinetics of reaction between T-1824 and liver slice in mixtures of plasma albumin. Am. J. Physiol., 1951, 164, 123.

34. Eisen, H. N., and Keston, A. S., The immunologic reactivity of bovine serum albumin labelled with trace-amounts of radioactive iodine $\left(\mathrm{I}^{131}\right)$. J. Immunol., 1949, 63, 71.

35. Knox, W. C., and Endicott, F. C., $\mathrm{I}^{121}$ as an antigen label in the circulating serum of non-immune rabbits. J. Immunol., 1950, 65, 523.

36. Latta, H., Experimental hypersensitivity in the rabbit. Blood and tissue concentrations of foreign proteins labelled with radioactive iodine and injected intravenously. J. Immunol., 1951, 66, 635.

37. Gitlin, D., Latta, H., Batchelor, W. H., and Janeway, C. A., Experimental hypersensitivity in the rabbit. Disappearance rates of native and labelled heterologous proteins from the serum after intravenous injection. J. Immunol., 1951, 66, 451.

38. Sterling, $K$., The turnover rate of serum albumin in man as measured by $\mathrm{I}^{131}$-tagged albumin. J. Clin. Invest., 1951, 30, 1228.

39. Phillips, R. A., Van Slyke, D. D., Hamilton, P. B., Dole, V. P., Emerson, K., Jr., and Archibald, R. M., Measurement of specific gravities of whole blood and plasma by standard copper sulfate solutions. J. Biol. Chem., 1950, 183, 305.

40. Freinkel, N., Schreiner, G. E., and Athens, J. W., Artifactual divergence of distribution compartments resulting from mixing T-1824 and $\mathrm{I}^{192}$-labelled albumin prior to injection. Manuscript in preparation.

41. Stewart, G. N., Researches on the circulation time and on the influences which affect it. IV. The output of the heart. J. Physiol., 1897, 22, 159.

42. Kinsman, J. M., Moore, J. W., and Hamilton, W. F., Studies on the circulation. I. Injection method: physical and mathematical considerations. Am. J. Physiol., 1929, 89, 322.
43. Moore, J. W., Kinsman, J. M., Hamilton, W. F., and Spurling, R. G., Studies on the circulation. II. Cardiac output determinations; comparison of the injection method with the direct Fick procedure. Am. J. Physiol., 1929, 89, 331.

44. Dow, P., Hahn, P. F., and Hamilton, W. F., The simultaneous transport of $\mathrm{T}-1824$ and radioactive red cells through the heart and lungs. Am. J. Physiol., 1946, 147, 493.

45. Lawson, H. C., Cantrell, W. F., Shaw, J. E., and Blackburn, D. L., Simultaneous comparison of two injection methods for cardiac output. Fed. Proc., 1952, 11, 90.

46. LeVeen, H. H., and Fishman, W. H., Combination of Evans Blue with plasma protein: its significance in capillary permeability studies, blood dye disappearance curves and its use as a protein tag. Am. J. Physiol., 1947, 151, 26.

47. Tyor, M. P., and Cayer, D., The rate of disappearance of iodinated human albumin from the serum in relation to albumin concentration, total circulating albumin content, and the presence of ascites in patients with cirrhosis. J. Lab. \& Clin. Med., 1952, 39, 874.

48. Forker, L. L., and Chaikoff, I. L., Turnover of serum proteins in diabetes as studied with $S^{2 x}$-labelled proteins. J. Biol. Chem., 1952, 196, 829.

49. Miller, L. L., Bale, W. F., Yuile, C. L., Masters, R. E., Tishkoff, G. H., and Whipple, G. H., The use of radioactive lysine in studies of protein metabolism; synthesis and utilization of plasma proteins. J. Exper. Med., 1949, 90, 297.

50. Yuile, C. L., Lamson, B. G., Miller, L. L., and Whipple, G. H., Conversion of plasma protein to tissue protein without evidence of protein breakdown; results of giving plasma protein labeled with carbon 14 parenterally to dogs. J. Exper. Med. 1951, 93, 539.

51. Fink, R. M., Enns, T., Kimball, C. P., Silberstein, H. E., Bale, W. F., Madden, S. C., and Whipple, G. H., Plasma protein metabolism-normal and associated with shock; observations using protein labeled by heavy nitrogen in lysine. J. Exper. Med., 1944, 80, 455.

52. Freinkel, N., Schreiner, G. E., and Athens, J. W., A new method for measuring transcapillary exchanges : the transfer of salt and water in the lesser circulation of man. J. Clin. Invest., 1952, 31, 629.

53. Miller, W. S., The Lung. Springfield, Ill., Charles C Thomas, 1937, p. 72.

54. Miller, W. S., The Lung. Springfield, Ill., Charles C Thomas, 1937, p. 84.

55. Unger, P. N., Zuckerbrod, M., Beck, G. J., and Steele, J. M., Study of the disappearance of Congo Red from the blood of non-amyloid subjects and patients with amyloidosis. J. Clin. Invest., 1948, 27, 111. 
56. Freinkel, N., Smith, W. W., and Miller, A. M., Unpublished observations.

57. Cannan, R. K., The chemical analysis and characterizations of plasma substitutes. Progress report, National Research Council Subcommittee on Shock, August 15, 1951.

58. Klotz, I. M., and Walker, F. M., The binding of organic ions by proteins. Charge and $\mathrm{pH}$ effects. J. Am. Chem. Soc., 1947, 69, 1609.

59. Hughes, W. L., Jr., and Straessle, R., Preparation and properties of serum and plasma proteins. XXIV. Iodination of human serum albumin. $\mathrm{J}$. Am. Chem. Soc., 1950, 72, 452.

60. Storey, R. H., Moshman, J., and Furth, J., A simple procedure for determination of the approximate lymph space. Science, 1951, 114, 665.

61. Masouredis, S. P., and Melcher, L. R., Blood, plasma and "globulin" space of guinea pigs determined with $I^{181}$ rabbit globulin. Proc. Soc. Exper. Biol. \& Med., 1951, 78, 264.

62. Sterling, K., Serum albumin turnover in Laennec's cirrhosis as measured by $\mathrm{I}^{13}$-tagged albumin. $\mathrm{J}$. Clin. Invest., 1951, 30, 1238.

63. Miller, A. T., Jr., Excretion of the blue dye T-1824 in the bile. Am. J. Physiol., 1947, 151, 229.

64. Wasserman, K., and Mayerson, H. S., Exchange of albumin between plasma and lymph. Am. J. Physiol., 1951, 165, 15. 